\title{
FOUNDERS OF DOMESTIC BYZANTINE STUDIES. THE RETURN OF FORGOTTEN NAMES IN MODERN HISTORICAL SCIENCE
}

\section{Lilia Kulykova ${ }^{1}$}

DOI: https://doi.org/10.30525/978-9934-26-077-3-13

Abstract. The subject of the research is the study of scientific researches of personalities, biographies and creative way of outstanding domestic scientists, scholars of Byzantium in the second half of the 19th - first half of the 20th century, who became the founders of Byzantine studies. Research methods. A system of theoretical and empirical research methods was used to study the specific purpose of scientific research and solving problems, namely: historical and pedagogical analysis and synthesis, definition of the purpose, subject and tasks, exploration, synthesis of abstraction, comparison, generalization and analogy to clarify the peculiarities of the development of theoretical approaches underlying the renewal and expansion of the study of Byzantinists and their research on the specified topic; analysis of sources, as well as research materials with the subsequent synthesis of its results into a holistic system of views on this problem; personalistic and biographical method - for the analysis of historical, biographical, reference and encyclopedic literature devoted to historical and pedagogical personalities. The aim of the study is to present to modern historians and all those interested in studying the history of Byzantium, both in Ukraine and abroad, the names of prominent historians of the past and objectively evaluate their work and scientific results in terms of modern international scientific views and approaches. Conclusion. Personalized study of life and scientific and pedagogical heritage of professors and academics of Byzantine studies V. G. Vasilievsky, O. O. Vasiliev, V. E. Regel, Y. A. Kulakovsky, F. I. Uspensky, A. G. Gotalov-Gottlieb gave the opportunity to reveal their fundamental role in the development of domestic Byzantine studies, the establishment of their own scientific schools and areas in scientific and pedagogical activities, created scientific and educational literature on

${ }^{1}$ Dr. of Pedagogical Sciences, Professor,

First Vice-Rector of Kherson State Maritime Academy, Ukraine 
Byzantine history, medieval history and culture, national foreign research institutes, scientific societies, associations and more. The scholars in their monographs and textbooks gave a personal vision of the problem and an interpretation of the expediency and importance of studying the history and culture of Byzantium and the Middle Ages in general. V. G. Vasilievsky, O. O. Vasiliev, V. E. Regel, Y. A. Kulakovsky, F. I. Uspensky, A. G. GotalovGottlieb laid the foundation of the national scientific championship. Their names and works are our scientific pride «forgotten», «shot», destroyed or simply unknown today to the general public of modern scientists in Ukraine and abroad. Further research of publications and use of their works and textbooks could become a valuable source for modern researchers of Byzantine history, as well as a discovery and subject for acquaintance for modern foreign researchers.

\section{Introduction}

In the domestic historical and pedagogical science now there is a unique opportunity not only to rediscover many names of great scientific authorities of the past, but also to study, analyze and, most importantly, objectively assess the relevance of their work and scientific activity from the modern point of view. All this applies, first of all, to the scholars who stood at the sources of domestic Byzantine studies - a branch of science that comprehensively studies everything related to the history and culture of the Byzantine Empire, as well as its impact on international relations and historical significance.

It so happened that throughout the XX century the works of scholarsByzantinists in our country have not been widely studied, and therefore not published. And this is understandable, because if a scientist devoted his life to the study of the Byzantine Empire, he had to express his opinion about religion, the influence of the church on public affairs, evaluate specific people, express their attitude to classes, social groups, movements, and this is very often did not coincide with the official views of specific royal figures, revolts or popular movements. That is why the activities and scientific achievements of many scholars-Byzantinists were simply silenced.

The purpose of our study is to reveal the scientific activities of the founders of the domestic Byzantine Studies, namely: Vasily Grigorovich Vasilievsky and his students and colleagues - V. E. Regel, Y. A. Kulakovsky, 
O. O. Vasilyev, F. I. Uspensky and A. G. Gotalov-Gottlieb - scientists and teachers-practitioners, who we should be proud of for their titanic work in the field of Byzantine Studies, because they were all primarily individuals, encyclopedists, teachers who left behind entire scientific schools. We believe that this is relevant, especially from the point of view of science, especially pedagogy, because modern students and young scientists must not only know their names, but be able to study their life and scientific path as a good example to follow.

The scientific novelty of our study is to present the scientific achievements of these scientists-educators in the world science of Byzantium, which in the XX century no one managed to surpass. Suffice it to say that the work of F. I. Uspensky was recognized as the only and largest study of the history of the Byzantine Empire in the XX century.

\section{Vasily Grigorovich Vasilievsky (1838-1899) is considered the founder of national Byzantine studies}

He certainly has the first place. He was born in the village Ilyinskoe, Yaroslavl province in the family of a village priest. He studied at the Yaroslavl seminary, the main pedagogical institute, and after the closure of the institution in 1859, at the historical and philological faculty of St. Petersburg University. In 1862 Vasyl Gryhorovych went abroad to complete his education. Here, at the University of Berlin, together with Y. A. Kulakovsky, he listened to lectures by the great Theodor Mommsen, as well as Droysen and Adam Schmidt in Jena. After returning to Russia, V. G. Vasilievsky was enrolled as a history teacher in the Vilnius Gymnasium. After defending his dissertation on «Political Reform and the Social Movement in Ancient Greece in its Decline» in 1869, the young scholar taught a course in medieval history at St. Petersburg University, as well as at the Imperial Alexander Lyceum, the Theological Academy, and the Higher Women's Courses.

In 1876 V. G. Vasilievsky was elected a corresponding member, and in 1890 an ordinary academician on Russian and Byzantine history. From the same year his editorial activity began in the «Journal of the Ministry of Public Education» (hereinafter JMPU). As a teacher, V. G. Vasilievsky actively showed himself in the work of the scientific committee of the Ministry of Public Education and in the archeological commission. 
V. G. Vasilievsky wrote almost sixty scientific articles on ancient Russian, Russian-Lithuanian history, on the history of geography and ethnography. But his main research was works on the history of Byzantium and ByzantineRussian and Bulgarian history, which were published in such prestigious journals and collections as "Vestnik Evropy", "JMPU", "Kurier Wileński", "Orthodox Palestine", "Slavic Collection" (vols. 1-2), "Russian Archive", "Dictionary of Vengerov". And his fundamental works "The story of Epiphanius about Jerusalem and the people living in it in the first half of the IX century", translated and explained by V.G. Vasilievsky from Greek texts and appendices (1886), translation of G.V. Stoll's book "Heroes of Greece in the war and peace" $(1868,1879)$, "Nicholas Bishop of Mephon and Fyodor Prodrom, writers of the XII century, life of Meletius the New", published with a preface and Russian translation by V. G. Vasilievsky (1886), "Review of works on Byzantine history" (issue 1, 1890) and "Russian-Byzantine Studies" (two issues, 1893), which was published by the Academy of Sciences of Russia three times in 1908, 1909 and 1915 [1, p. 431].

The most famous and valuable scientific publications of V.G. Vasilievsky on the history of Byzantium are "Iconoclast Legislation" (1878), "Materials for the internal history of the Byzantine States" (1879), "Byzantium and the Pechenegs" (1872), "Russian-Byzantine Excerpts" (1875-1878, 1889), "On the Life and Works of Simon Metafrats" (1880), "Restoration of the Bulgarian Patriarchate under Tsar Ion Arsene II" (1885), etc. [2, p. 794].

V. G. Vasilievsky published with his comments a number of monuments of Byzantine history, for the first time revealed the meaning of economic terms and covered many issues in the history of farming in the ancient state.

V. G. Vasilievsky founded and was the first editor of the scientific Journal "Vizantiyskiy Vremennik", and until now, for more than a century, its pages have published the most famous works of the twentieth century in this field of knowledge.

V. G. Vasilievsky died in Florence on May 13 (25), 1899, and was buried in the Lutheran Cemetery (Allora).

\section{Vasily Eduardovich Regel - the first rector of Voronezh State University}

After the death of V. G. Vasilievsky, the Journal was headed by Vasily Eduardovich Regel, who from the very beginning of the publication, as 
the second editor, solved all issues related to logistics, corresponded with foreign, including Greek, scientists, with the Athos monasteries, while not receiving pay for this work. It was thanks to V. E. Regel that the publication gained great fame in the relevant scientific circles (it was put on a par with Byzantishe Zeitschrift, the authoritative journal of Karl Krumbacher, published in Munich in 1892). When in 1915 the edition of the magazine was handed over to F. I. Uspensky, V. E. Regel began to publish the Byzantine Review (three volumes were published by 1917). The Journal covered issues of church history, philology, history and geography, law, art and archeology of Byzantium.

V. E. Regel (Andreas Friedrich Wilhelm Regel) was born on November 27, 1857 in St. Petersburg in the family of a rich nobleman E. L. Regel, who was a famous botanist, a corresponding member of the Russian Academy of Sciences.

After graduating from the St. Petersburg Reform School, the future Byzantinist studied at the Faculty of History and Philology of St. Petersburg University (he graduated in 1880). Then there was the preparation at the same faculty for a professorship in general history and the service of a clerk at the Department of Public Education. In 1894, on the recommendation of V. G. Vasilievsky and V. I. Lamansky, V. E. Regel was sent abroad for two years to study the methods of teaching history at German universities, to make useful acquaintances, to study Greek paleography in Berlin or Leipzig, political and ecclesiastical history of Byzantium in connection with and comparison with Western and Slavic, not limited to chronicles and printed sources, but also directly acquainted with the Greek-Slavic East, as well as to study medieval Greek literature, dialects of modern Greek in their historical development. During this time he visited and worked in the archives and libraries of Athens, Berlin, Paris, Rome, Vienna, London, Barcelona and other cities [4, p. 130-139].

During this and the next (1889) business trip, V. E. Regel met with leading German and Austrian scholars who studied the history of Byzantium, Schrett, G. F. Herzberg and Gelzer. Working in the bookstores of Constantinople and other cities in Asia Minor, Athens, Thrace, Fr. Patmos, a young scholar, not only studied unexplored sources, but also found many unknown materials from Byzantine and Slavic history 
and copied many of them, including "chrysobull". And in Thrace he determined the location of several settlements mentioned in the works of ancient writers: Abdera - the first port city of the region on the Aegean Sea, on the site of which later grew the city of Polystylon; ancient Lydian mountain Daskalia, and clarified the location of the ancient Buro-Kalessi on the northern shore of the sea bay Burugel. The scientist has collected a rich collection of inscriptions of the Greek, Roman and Byzantine eras. According to the materials of business trips, V. E. Regel published a number of articles on Byzantine epigraphy and paleography, which contributed to the development of Russian science.

His master's thesis "On the Chronicle of Cosmas of Prague" was highly praised by the scientific community.

Returning to his homeland in 1888, V. E. Regel until 1908 worked as a private associate professor at St. Petersburg University, where he lectured and conducted practical classes on the history of Byzantium.

In 1898 , the scientist was elected a corresponding member of the Russian Academy of Sciences. Since 1913 he was an extraordinary professor at St. George's (Tartu) University; since 1914 - ordinary professor of the same university and professor and acting rector of the Higher Women's Courses in St. George, and on October 10, 1917 he was awarded the title of Honored Professor. When World War I broke out, St. George's University was evacuated to Voronezh. Here V.E. Regel not only taught, but also worked for some time as rector of the university, and also founded the Art ethnographic museum. The scientist and teacher died in Lithuania in Kaunas on December 1, 1932, where he emigrated.

V. E. Regel was one of those leading scholars who believed that for the most accurate idea of the historical processes in Byzantium, the source base of history must be studied comprehensively, and for this you need to know ancient and new languages, archeology, auxiliary historical disciplines: paleography, epigraphy, historical topography and others, freely navigate the world literature created about the ancient state in modern times. Few European scholars had such erudition and V. E. Regel belonged to them [5].

Another well-known and now forgotten scientist O. O. Vasiliev, belonged to V. G. Vasilievsky's school. 


\section{Alexander Alexandrovich Vasiliev - the first researcher of Byzantium's relations with the Arab world}

Professor of Tartu University (since 1904), and since 1912 - Professor of St. Petersburg University. In history of Byzantine studies, he entered as a researcher of Byzantium's relationship with the Arab world. O. O. Vasiliev devoted His master's and doctoral thesis to this question ("Byzantium and the Arabs. Political relations between Byzantines and Arabs during the Amorian Dynasty", St. Petersburg, 1900 and "Byzantines and Arabs during the Macedonian dynasty, 867-957", St. Petersburg, 1902). The works were based on a large amount of factual material, and they were immediately included in those major scientific studies of the world importance.

O. O. Vasiliev was born in 1867 in St. Petersburg in a military family. His father, Alexander Stepanovich, was the commander of the fortress team in St. Petersburg. After graduating from the First Classical Gymnasium in 1887, he entered the St. Petersburg Conservatory in the class of theory and composition, as well as the Department of History of the Arab East of St. Petersburg University. A year later he left the conservatory, but did not part with music all his life, and when he emigrated to the United States he became an outstanding pianist, and he devoted his entire life to history.

Earlier in 1892, when he was still studying at the university, his Arabic teacher V. R. Rosen recommended him to Academician V. G. Vasilievsky. This finally determined his further scientific path.

From 1897 to 1900 he was an intern in Paris. In 1901 he defended his master's thesis on "Political relations between Byzantines and Arabs during the Amorian Dynasty".

Together with N.Y. Marr he traveled to Sinai, to the monastery of St. Catherine, and then to Florence. In the same year, 1902, he defended his doctoral dissertation on "Political relations between Byzantines and Arabs during the Macedonian dynasty (867-957)".

From 1904 to 1912 - O.O. Vasiliev, Professor of Tartu University at the Department of World History.

From 1912 to 1922 he worked as a professor and dean of the historical and philological faculty of the Petrograd Pedagogical Institute, a professor at St. Petersburg University.

In 1925 he was on a business trip abroad in Berlin, Paris, and then in the United States, for which June 2, 1925, by decision of the general meeting, 
he was expelled from the USSR Academy of Sciences. And after that he decided not to return home.

From 1925 to 1938 he worked as a professor at the University of Wisconsin. In 1934 he was elected a member of the Yugoslav Academy of Sciences, and later - president of the N. P. Kondakov Archaeological Institute in Prague (from 1935 to 1957), a member of the American Academy of the Middle Ages, chairman of the International Association of Byzantine Studies).

Alexander Vasiliev - founder of American Byzantology. While in America, he began researching Byzantine cultural monuments, which were housed in museums in Philadelphia, Harvard, etc.

Since 1941, O. Vasiliev began to publish his own periodical "Dumbarton Oaks Papers" which published articles not only on Byzantine topics, but also on the study of antiquity and the Middle Ages.

At this time in America, the Byzantine was not yet studied as an independent scientific field, and this is what O. Vasiliev did. In the first year of his stay, he translated his book "History of Byzantium", which for many years became a textbook for American students. All his later life he worked in America developing problems in the study of Byzantine history. In 1953, at the Byzantine Congress in Thessaloniki, he was elected honorary president of the Congress.

O. Vasiliev was buried in Armenia on March 22, 1990. Already in our time he was posthumously returned the honorary title of corresponding member of the USSR Academy of Sciences [6].

\section{Julian Andreevich Kulakovsky - a prominent Ukrainian Byzantinist}

Y. A. Kulakovsky (July 13 (25), 1855. Ponevezh - February 21, 1919, Kyiv) - was a historian, archaeologist, translator from Latin and ancient Greek, publicist, teacher, who devoted his life to studying the history of the Roman and Byzantine empires.

Unlike V. E. Regel and O. O. Vasiliev, his fate was more generous to him - he was widely known both in life and after. A well-known professor at the University of Kiev, a great specialist in the history of ancient Rome and Byzantium, he followed a traditional path: first Moscow University, a trip abroad, where he listened to the aforementioned Mommsen, Gudshmidt and 
others; after returning in 1882 to the Motherland, he defended his master's thesis (probably, this is the first doctoral dissertation defended by a historian in Ukraine on the history of mythology).

Since 1881, Y. A. Kulakovsky was teaching Roman literature and Latin and Roman history and literature at Kyiv Higher Women's Courses, and was taking part in the excavations of the Pantikapaion (modern Kerch).

In his work "The Christian Church and Roman law for the First Two Centuries" (1891), Y. A. Kulakovsky argued that religious intolerance was uncharacteristic of Roman law and became characteristic of it only under Christian emperors. This outraged the Kiev clergy, and they declared the scientist «the new apostate Julian» [7], so Y. A. Kulakovsky was forced to reprove the truth of his thoughts in the "University Gazette» (1892). Yulian Andriyovych paid special attention to this question in his work "History of Byzantium" (in 2 volumes), written on a lot of documentary material.

As a historian of ancient Rome and antiquity, Y. A. Kulakovsky was known for the following works: "Politics of the Athenians" (1881), "Suetonius and his biography of Caesar", "Rulers of the Roman provinces" (1882), "The oldest period of the Roman Empire" (1884) and others.

In the historical science of the Soviet period, Y. A. Kulakovsky's works were not widely known, because he was a "pre-revolutionary" and, consequently, a bourgeois scholar, so his works were not republished or even mentioned.

In the second half of the 1890, Y. A. Kulakovsky was the first scientist to conduct archeological excavations in the south of Ukraine in Olbia, and one of the first, together with K. E. Dumbert in Kerch and the Old Crimea.

Y. A. Kulakovsky during his life participated in all the Archaeological Congresses (1884-1908), was a delegate to the Riga International Historical Congress (1903), the Berlin Congress of Historians (1909), the III International Congress of Historians in Leiden (1912), was a member of the Imperial Archaeological Commission, as well as vice-chairman of the Kyiv Art, Industry and Science Museum of Emperor Nikolai Alexandrovich, a member of the Board of Trustees of the Kyiv Educational District.

The main scientific work of his life was a three-volume "History of Byzantium" - it was the first work composed by Ukrainian scholar, a chronicle of the central events of the Roman Empire from the founding of Constantinople (359) to the reign of Leo Isaurus (717). 
Y. A. Kulakovsky was a monarchist and took an active part in the monarchical movement. In 1909 he was elected to the Council of the Kyiv Club of Nationalists, participated in the conservative movement.

There are very interesting memories of Y. A. Kulakovsky's students about him as a teacher. Students were especially impressed by his extensive erudition, knowledge of languages, his subject and high professionalism and pedagogical skills. He never used any notes or abstracts in his lectures, his lectures were very interesting and informative. For example, V. F. Asmus, a student of the Faculty of History and Philology of the University of St. Vladimir in Kiev, in his memoirs painted the following "portrait" of his teacher: "Kulakovsky was already an old man, but extremely cheerful, lively and energetic. He was wearing a well-tailored civilian suit, elegant trousers and exquisite socks. Entering the audience, he quickly greeted us, looked at us with a very stern look and immediately, without any preface, began reading. He read vigorously, swiftly, and each phrase spoke of great learning, of impeccable mastery of the subject, of pedagogical skill. He did not use any notes or abstracts. He warned us not to think of using Modestov in preparation for the exam, and was extremely unflattering about his course. He immediately advised not to prepare for his own lithographed lectures. He recommended that you first keep your own records and prepare for the exam. When the lecture began, we looked at each other and thought that he was probably exaggerating our abilities and our willingness to record his complex course, which he also read at a fast pace and sprinkled with Latin quotations from the most ancient monuments of Roman literature... The lectures were informative and interesting, and Kulakovsky's temperament made them lively, sometimes dramatic. We fully appreciated these qualities of Kulakovsky when he reached Plautus and began to analyze the content of his comedies. In the audience, there was often a chorus of laughter. Especially memorable are the retellings of the comedies Aulularia [The Pot], Menechmi [Two Menechmas], Miles gloriosus [The Boastful Warrior]. Kulakovsky conducted his masterful retellings extremely seriously, without a shadow of a smile - while listening to him, we often laughed uncontrollably ... Kulakovsky's temperament was political. This was a professor who did not hide his «right» political convictions, his readings were saturated with a political tendency. Both the heroes of the historical and literary process itself, and the learned luminaries - Western and 
domestic - of the history of Roman literature were portrayed in his course as carriers of valiant or harmful political principles that they embodied. Such were Kulakovsky's images of Ennius and Lucretius, and Caesar and Cicero, and Curtius and Mommzen" (Memories of V.F. Asmus ... / Compiled by M. A. Abramov, V.A. Zhuchkov, L. N. Lyubinskaya. M., 2001. pp. 212-213). Yulian Andreevich conquered with "learning, brilliance of erudition, enormous memory".

V. A. Romanovsky (1890-1971), student of the Faculty of History and Philology of the University of St. Vladimir in 1909-1914: "Greek and Roman literature was represented quite strongly. In particular, the professor of Roman literature Y. A. Kulakovsky enjoyed great influence. He was a student of the St. Petersburg professor V. G. Vasilievsky and especially the Berlin professor T. Mommsen. For philologists, Y. A. Kulakovsky read "On the nature of things" by Lucretius Kara, for historians - Tacitus, Titus Livy, etc. He was especially fond of Roman writers and then moved on to the history of Byzantium..." (Alma Mater: University of St. Vladimir on the eve and in the days of the Ukrainian revolution (1917-1920): materials, documents, memoirs / Auth.-order. V. A. Korotkiy, V. I. Ulyanovskiy. Kiev, 2000. Book 1, p. 287).

Y. A. Kulakovsky died in Kyiv. In the scientific community he was considered a student of V. G. Vasilievsky and T. Mommzen [8].

\section{F. I. Uspensky - outstanding Ukrainian Byzantinist, founder of the Archaeological Institute in Constantinople}

Fedor Ivanovich Uspensky (1845-1928) was another of the founders of domestic Byzantine studies, closely connected with Ukraine. From 1879 to 1894 he held the position of professor at Novorossiysk University, so we have the right to call him a Ukrainian scientist.

F. I. Uspensky entered the annals of world history about Byzantium as the author of the fundamental work on Byzantine studies "History of the Byzantine Empire" [9], which covered the history of this country and neighboring states in the period from V to XV centuries, and the founder of the Russian Archaeological Institute in Constantinople (1894-1914), which he also headed.

F. I. Uspensky studied a huge number of Byzantine, Slavic, Western European, and Eastern sources, and introduced many of them into scientific circulation. 
At the end of the XIX century Byzantine studies in the Russian Empire occupied a leading place in this field of knowledge. Russian Byzantinists raised many issues of Byzantine history for the first time and made significant amendments to its interpretation. Even Soviet historians emphasized that they had inherited from ancient times a huge amount of material without which science could not do. This was especially true about the works of F. I. Uspensky, because he first published extremely valuable materials on the history of Slavic peoples of the Balkan Peninsula, in particular Serbia and Bulgaria. F. I. Uspensky traced the history of Serbia from the time of the emergence in the XI century of the first state formations of the coastal Serbs to the conquest of the region by the Turks. The scholar studied in detail the political history of the Bulgarian kingdom, the Latin feud, possession in the Byzantine Empire after its conquest by the Crusaders, analyzed and described the history of Byzantine-Venetian relations of the Palaeologus epoch in the period of its gradual decline. He vividly described the difficult international situation at that time, showed the Norman danger threatening the empires from the West, the growing power of the Slavic states of the Balkan Peninsula, the penetration of Italian merchants into Byzantium, which they destroyed inside, and finally the emergence and steady growth new danger from the Ottoman Turks, etc.

At first glance, it seems unclear why Soviet historical science has forgotten the scientist it should be proud of. What did they accuse him of?

First of all: protection of the small peasant community, monarchism, glorification of reforms from above and sharply negative attitude to national movements, class struggle; protection of the Orthodox Church as the basis of statehood; exaggeration of the importance of church issues in history, as well as the preaching of evolution instead of revolution, reforms instead of class struggle; religious views of the scientist, the ideas of nationality, Orthodoxy and the nation-state, because in Soviet times it was impossible to stutter that religious and ecclesiastical activities had a positive and decisive role in the historical development of the vast empire. Soviet historians rejected Uspensky's scientific conclusions, evaluating him and his scientific works as bourgeois, idealistic and positivist.

The idea of protecting peasant free property runs like a red thread throughout the "History of the Byzantine Empire". Moreover, the author closely intertwines the interpretation of this issue with monarchist and 
reformist ideas, emphasizing that the monarchical government itself should be concerned about strengthening free peasant land ownership by carrying out reforms. Such, according to F. I. Uspensky, was the activity and rule of the emperors of the Macedonian dynasty, who pursued a policy of protecting free peasant land tenure from the oppression of the feudal lords. For Uspensky the policy of the Macedonian emperors was a model of combining reformist activities in favor of small peasant landholdings with strong monarchical power.

Today's reading of this work at the beginning of the XXI century impresses with its relevance and modern sound, richness of thought, erudition of the author, the depth of scientific reasoning, so it is rightly considered unsurpassed in European historical science.

Note: it was F. I. Uspensky who for the first time in domestic science gave a definition of "Byzantinism". As an expression of political, cultural and philosophical and literary features, Byzantium is manifested in the following features: 1) in the gradual abolition of Latin, which was dominant in that state at that time, and its replacement by Greek or Byzantine; 2 ) in the struggle of nationalities through political domination; 3 ) in the original nature of art development [9, p. 40].

F. I. Uspensky tried to prove that Byzantium was the beginning of historical development in South-Eastern Europe [9, p. 41]. According to the scientist, Byzantium became the ideal of the Slavic kingdom, to which the advanced Slavic peoples aspire. Byzantium «goes» to Kiev and Moscow, under its leadership there is a historical life, the state and military system of the south-eastern Slavs [9, p. 41].

In the introduction to the work F. I. Uspensky emphasized that he devoted 40 years of his life to the study of Byzantine history. The scientist studied it in Russia, in Constantinople, in the libraries of monasteries, and in European libraries for one purpose only: "... To give such a book to the Russian reader, which, on the one hand, with its clarity and seriousness would give him an idea of a well-thought-out and balanced system, and on the other - would leave a good memory of the author, who dared to let the history of Byzantium in the world. The author was subject to the inner urge, which stemmed from the conviction: the assertion of knowledge about Byzantium and clarifying our attitude to it is most mandatory for the scientist and no less useful for education and for direction in the correct 
course of political and national identity. Let the reader reflect on the content of the chapters devoted to the South Slavs and look there for illustrations of the sad events that are now taking place on the Balkan Peninsula" [10, p. 14-126].

In one of the rare book collections of the National Scientific Library named after V. I. Vernadsky, we managed to find interesting materials about F. I. Uspensky as a teacher-professor and supervisor. These are the memories of A. G. Gotalov-Gottlieb, one of the closest students of Fyodor Ivanovich. A. G. Gotalov-Gottlieb writes that Uspensky's students respected him for his passion, devotion to science, strictness to himself and demanding of his students, for the great talent of a teacher. He could present the most complex and confusing phenomena clearly and intelligibly, without admiring the details and artistically highlighting the essential. F. I. Uspensky prepared very carefully for lectures, so he read without notes, except that he kept a sheet with a plan of lectures at the department. Teaching the prehistoric period of Greece in the course of the history of antiquity, the professor used the conclusions of archeology and comparative philology, being very careful about mythology. In the course of the Cretan-Mycenaean and Homeric periods, he acquainted students with the views of world-famous European scientists such as Wolf, Grotto, Cox, Bergk, Folkman, Thucydides, Plutarch, Straton, Sheman, Terman, Beck, Waxmuth, Cortius, Kuhn Gilbert, Schmidt, Ulrich, Klassen, Buzolt, Bloch, the works of Pausanias and others. It should be noted that he read the works of these scientists in the original. And teaching the course of ancient Rome, Fyodor Ivanovich relied on the work of especially popular authors Niebuhr, Mommsen, Schweler, Durui and others [11, p. 14-126].

Creating his own method of university teaching and leadership of students' sci-entific classes, F. I. Uspensky sought, wherever he could, examples for comparison, analyzed the techniques and methods of other teachers, selecting the best for him. F. I. Uspensky acquainted students with the works of such scientists as Zeiss, Drinov, Tomen, Galatsky, Hilferding, Lamansky, Leontovych, Kotlyarevsky, Vostokov, Sreznevsky, Bodyansky, and many others. Gotalov-Gottlieb emphasizes that F. I. Uspensky deviated from the tradition of lecturing in front of a silent audience, and he activated the listeners' attention by asking them questions. At the end of the semester he usually held colloquia. The crown of the teacher's scientific 
and pedagogical work were practical classes on the history of the Middle Ages, in which students read and explained the main sources of Tacitus, Procopius, Constantine the Crimson, «barbaric truths», capitulations, formulas, passages from chronicles and more. The professor thoroughly characterized each source, indicating its origin, probability, condition, and also commented. At the seminars, he distributed among students two or three topics of essays. The abstract had to be submitted to him in advance. At a certain time, the author of the abstract read his work or part of it, then the professor analyzed the work, and if it was assessed as satisfactory, it was a huge compliment to the student [10, p. 14-126].

The library of Odessa University has a list of books that F. I. Uspensky took in it during 1875-1894. The list is impressive in the number and variety of books.

The fact that all scientific activity in Byzantine studies at Novorossiysk University was based on F. I. Uspensky is evidenced by the fact that when he went to Constantinople in 1894, it began to decline, and even the "community of Byzantinists", created by him, was disintegrated. N. K. Kondakov, later a well-known specialist in the field of art, went to St. Petersburg, and historian A. I. Kirpichnikov went to Moscow University.

F. I. Uspensky entered the national history of science as the founder of the first scientific society for the study of history, archeology, art, and the Christian East abroad in the Ottoman Empire. He organized it and became the first director.

In 1894, Emperor Alexander III approved the Charter and staff of the newly established Archaeological Institute, and later the Journal "Izvestia RAIK" was founded, in which the results of scientific research were published.

The main purpose of the newly established institute was to study ancient geography and tomography, study the history and archeology of all territories of historical Byzantium, description of manuscripts, epigraphy and numismatics, study of architecture and monumental monuments. The Russian government has obtained permission from the Porte to conduct excavations throughout the territory and the possibility of keeping half of all finds. But, unfortunately, this work did not last long, it was stopped at the beginning of the First World War. In December 1914, all the property of the institute was confiscated by the Turkish government and transferred to the Ottoman Museum, and in May 1920 the institute was liquidated. 
While in Constantinople before the war, F. I. Uspensky continued to give lectures to students - tourists from Russia and Ukraine, personally introduced them to the institute, museums, he led excursions to Hagia Sophia.

Already in the Soviet era, in 1927-1928, F. I. Uspensky dreamed of resuming the study of Byzantine history and culture at the Odessa University. He wrote: "Until I leave the stage, I would like to give hope for existence to Byzantinism in Russia after me" (quoted in: [7]). But years will pass until the exhibition "Byzantium and the Slavs" dedicated to the memory of the outstanding Byzantine scientist would be opened in Odessa in 1945. But his dream of the revival and development of Byzantology in our country is still unrealized, and therefore relevant [12].

\section{Artemy Grigoryevich Gotalov-Gottlieb - a famous scientist who studied Byzantine and a prominent representative of the scientific school of $F$. I. Uspensky}

Artemy Grigorievich Gotalov-Gottlieb - was born on January 5, 1866 in one of the townships of Belarus.

In 1889, having accepted Lutheranism, he entered the Faculty of History and Philology of the Imperial Novorossiysk University, which he successfully graduated in 1893. Gotalov-Gottlieb's graduation work “On the military structure of the Byzan-tine Empire" was carried out under the guidance of the outstanding Byzantinist Fyodor Ivanovich Uspensky.

In 1895 he accepted Russian citizenship (before that he was a citizen of the Austro-Hungarian Empire).

After graduating from the university with the 1st degree diploma, Gotalov-Gottlieb taught Latin at the gymnasiums. At the same time, GotalovGottlieb was a contributor to the Brockhaus and Efron Encyclopedic Dictionary and the author of dozens of fundamental articles on the history of education and world history.

Since 1899 , Gotalov-Gottlieb was a permanent member of the imperially established commissions for the improvement of secondary schools. He repeatedly went on business trips abroad to Switzerland, France, Germany, Austria-Hungary, where he got acquainted with the educational systems developed in European countries. The analysis of what he saw and the observations of the scientist were highlighted in his scientific publications, 
especially those devoted to the dissemination of the pedagogical ideas of John Dewey in Russia.

In 1903 he was appointed director of the Yalta gymnasium, and then headed the gymnasiums in Chisinau and Pskov. He was the director of the 2nd Chisinau gymnasium (1908-1910). From 1910 to 1918 he was the director of the Pskov men's gymnasium and taught Latin and history there. He became the prototype for Nikolai Antonovich Tatarinov, one of the most "negative" characters in the novel «Two Captains» by Veniamin Kaverin (who was studying at the gymnasium at the time). In Pskov, Gotalov-Gottlieb skillfully organized work on the physical education of students according to the Sokol system, initiated the creation of two sports societies - the Pskov Gymnastics Society "Sokol" and the Pskov Society for the Promotion of Physical Education of Students, led the Pskov Military Sports Committee. On January 16, 1917, he received the rank of a full state councilor "for his work on the physical development and education of students".

At the beginning of World War I, in 1914, he adopted Orthodoxy and a new name, Artemy Grigorievich Gotalov-Gottlieb.

In 1918-1920 he taught at a women's gymnasium in Cherkassy, a real school and schools in Odessa; led the largest in the country, organized in 1919 in Odessa, home for street children under the name "Children's Town named after Comintern". Since that time, his life was associated with Ukraine.

In 1920, A. G. Gotalov-Gottlieb took part in the creation of the Odessa Institute of Public Education, where he taught world history and history of pedagogy, led a student pedagogical seminar. Five years later he received the title of professor of the first (highest) category.

In 1927-1940 A. G. Gotalov-Gottlieb worked at the institutes of Moscow, Kharkov, Kiev.

In 1940, without defending a thesis, he was awarded the degree of Doctor of Pedagogical Sciences. In the same year he returned to Odessa, where he became a professor at Odessa University. Remaining in Odessa during the occupation of the city by the Romanian-German troops, he temporarily stopped his teaching activities.

After the liberation of Odessa in 1944, he returned to work: he served as the dean of the history faculty of Odessa State University (1944-1946), simultaneously in charge of two departments: the history of the ancient 
world and archeology and pedagogy, and since 1946 - only the department of pedagogy. At the university he taught courses in the history of the Slavic peoples and Byzantium.

In 1952 he retired, but after that he continued to read special courses and supervise graduate students.

The range of interests of the scientific activity of Gotalov-Gottlieb, which lasted almost 70 years, was extremely wide. P. O. Karyshkovsky wrote about this: "The range of scientific interests of prof. A. G. GotalovaGottlib was broad and versatile: the history of Byzantium and the Slavic peoples, the history of the ancient world and its culture, classical philology and archeology, and finally, pedagogy and psychology - all these disciplines were in his field of vision. ... More than 200 works came out from under his pen - monographs, articles, notes, reviews, popular brochures, a significant part of which is associated with the history of pedagogical and social ideas. Death interrupted his work on three monographs - "Essays on the military structure of Byzantium", "Questions of public education in France on the eve of the 18th century bourgeois revolution", "History of the Richelieu Lyceum in Odessa". The last two books were almost complete".

A. G. Gotalov-Gottlieb thoroughly studied the history of Odessa. In the collective work "Odessa: Essay on the history of the hero city" he was the author of three chapters: "Prehistory of Odessa", "Formation of the city and its development in the first decades" and "Odessa in the $30-50$ s of the XIX century". It is also worth recalling the manuscript work of A. G. Gotalov-Gottlieb "Materials for the history of public education in Odessa: Historiographic sketch", the first part of which is kept in the department of manuscripts of the Odessa National Scientific Library named after M. Gorky.

The contribution of A. G. Gotalov-Gottlieb to historical science, in particular, the study of antiquity and the Middle Ages, was highly appreciated by other scientists, in particular, Professor P. O. Karyshkovsky.

A. G. Gotalov-Gottlieb was the author of dozens of works on pedagogy, in particular, comparative, which investigated the state of education and pedagogical thought in Germany, Switzerland, Italy, Czechoslovakia, etc., as well as in the Russian Empire, Ukraine and the USSR in different eras. Modern scholars highly appreciate the contribution of A. G. GotalovGottlieb to pedagogical science. 
The negative assessment of Gotalov-Gottlieb by S. Y. Borovoy did not concern the activities of Gotalov-Gottlib as a scientist, but affected his moral qualities.

Gotalov-Gottlieb died in Odessa on July 27, 1960 was buried in the second Odessa Christian cemetery.

\section{Conclusion}

Personalized study of life and scientific and pedagogical heritage of professors and academics of Byzantine studies V. G. Vasilievsky, O. O. Vasiliev, V. E. Regel, Yu. A. Kulakovsky, F. I. Uspensky, A. G. Gotalov-Gottlieb gave opportunity to reveal their fundamental role in the development of domestic Byzantine studies, the establishment of their own scientific schools and areas in scientific and pedagogical activities, created scientific and educational literature on Byzantine history, medieval history and culture, national foreign research institutes, scientific societies, associations, etc. [13].

Each of the scholars in his monographs and textbooks gave a personal vision of the problem and an interpretation of the expediency and importance of studying the history and culture of Byzantium and the Middle Ages in general.

V. G. Vasilievsky, O. O. Vasiliev, V. E. Regel, Yu. A. Kulakovsky, F. I. Uspensky, A. G. Gotalov-Gottlieb and their students laid the foundation of the national championship.

Further research of publications and use of their works and textbooks could become a valuable source for modern researchers of the history of Byzantium, as well as a subject for acquaintance for modern foreign researchers.

In Ukraine, during the Soviet era, for almost the entire twentieth century, Byzantine studies, as an independent field in historical science did not develop systematically, we can say that this development continued sporadically. There were serious ideological and political reasons for this: after all, such prominent scholars as O. O. Vasiliev, Yu. A. Kulakovsky, F. I. Uspensky had their own views and judgments about religion, the influence of the church on public affairs, the importance of the personality of the common ruler in a certain period of Byzantine history. At the same time, it happened that the author praised the activity of one or another ruler 
or clergyman, and a specific uprising or movement of the masses acquired a negative mark in the consideration. That is why the scientific achievements of many Byzantine scholars for a long time, during the Soviet era were silenced and not studied by students and historians.

Even worse were those who were forced to emigrate or ended their lives in Stalin's camps. First of all, we are talking about scientists whose period of the most fruitful scientific work fell on the pre-revolutionary period of life and activity, when in completely different conditions was the process of forming their political views and worldview in general.

V. G. Vasilievsky, O. O. Vasiliev, F. I. Uspensky, Yu. A. Kulakovsky and many others are luminaries, encyclopedists, teachers, who left behind plenty of prominent followers and founded scientific schools.

Today, their dream of the revival and development of Byzantine studies in our country is still relevant and, unfortunately, still unrealized.

Today we see that the problems associated with the study of world history, the history of Byzantium and other regions remain relevant and in many areas unresolved and little studied.

Over the last decade, modern, powerful schools of scientists have been established abroad in leading research institutions and universities, which have more opportunities to study little-known sources and documents. And the topic of studying the experience of the millennial history of Byzantium remains relevant and significant.

According to J. Shepard, editor of "The Cambridge History of the Byzantine Empire", the study of the empire, which lasted from ancient times to the Italian Renaissance, sheds light not only on the past but also on the geopolitical trends of the XXI century and international relations.

\section{References:}

1. The Big Encyclopedia / S.N. Yuzhakov. - St. Petersburg: Enlightenment, 1903. - Vol. 4. - P. 794.

2. The Big Encyclopedia / S.N. Yuzhakov. - St. Petersburg: Enlightenment, 1930. - T. 4. - P. 794.

3. Vasiliev Alexander Alexandrovich. URL: https://cutt.ly/0nlC38U

4. Lapteva L.P. Regel as a Byzantinist // Byzantium. Mediterranean. The Slavic world. To the XVIII International Congress of Byzantines. - Moscow: Moscow Publishing House. University, 1991. - P. 130-139.

5. Regel Vasily Eduardovich. URL: https://cutt.ly/UnlC84O

6. Vasilyevsky Vasily Grigorievich. URL: https://cutt.ly/PnlC7aC 
7. Proceedings of the Kiev Theological Academy. - 1892. - No. 5, 6: 1893. No. 2, 4 .

8. Kulakovsky Yulian Andreevich. URL: https://cutt.ly/9nlC5Oc

9. Uspensky F.I. History of the Byzantine Empire. - Moscow: Astrel, 2001. Vol. 1-5. 1.

10. Udaltsova Z. V. On the question of evaluating the works of Academician F.I. Uspensky // Bulletin of ancient history. - 1945. - No. 6. - P. 14-126.

11. Gotalov-Gottlieb A. F. I. Uspensky as professor and supervisor // Vizantiyskiy Vremennik. - 1945. - Vol. 1. - Book. XXVI. - P. 14-126.

12. Uspensky Fyodor Ivanovich. URL: https://cutt.ly/xnlC6FE

13. Gotalov-Gottlieb Artemy Grigorievich. URL: https://cutt.ly/3nlVqKc 